\title{
COVID-19와 두경부암
}

\section{장재원}

충남대학교 이비인후과학교실

\section{Head and Neck Oncologic Care During the COVID-19 Pandemic}

\author{
Jae Won Chang, MD, $\mathrm{PhD}^{+}$
}

Department of Otolaryngology-Head and Neck Surgery, Research Institute for Medical Science,

Chungnam National University College of Medicine, Daejeon, Korea,

Research Institute for Medical Sciences and Pathology, Chungnam National University College of Medicine, Daejeon, Korea

\section{$=$ Abstract $=$}

It is well established that cancer patients are more susceptible to infection because of the immunosuppressive status caused by both disease itself and anticancer treatment, including surgery and chemoradiation. Head and neck cancer (HNC) patients are generally at high-risk for coronavirus disease 2019 (COVID-19) infection and serious adverse outcomes. Although there is an urgent need for guidance in the delivery of safe, quality oncologic care, no international consented recommendation addressed the management of HNC patients in COVID-19 due to limited data. In this review, we summarized the consideration for head and neck oncologic care in the context of the COVID-19 pandemic, based on the data and the very recent recommendations from the Korean Cancer Association and National Cancer Center. COVID-19 should be taken into consideration in the comprehensive management of HNC patients, and multidisciplinary evaluation of multilevel surgical-risks, discussion of optimized strategy, and shared-decision-making with the patient are needed to maximize both the safety from infectious pandemic and outcome of surgical and oncologic care.

Key Words: Head and neck cancer $\cdot$ COVID-19 $\cdot$ SARS-CoV-2 $\cdot$ Pandemic $\cdot$ Head and neck oncologic care

\section{서론}

암 환자는 정상인에 비해 면역기능이 저하되어 있어 COVID-19 감염이 고위험군으로 개인 위생에 더 신경 써야 하며, 증상이 있는 암 환자의 경우 적극적이며 종합 적인 평가와 처치의 대상이 되어야 한다. 특히 두경부는 또한 원발 부위의 특성상 감염되었을 경우 진찰이나 수

Received: May 3, 2020

Revised: May 9, 2020

Accepted: May 10, 2020

+Corresponding author: Jae Won Chang, M.D., Ph.D. Assistant Professor, Department of Otolaryngology-Head and Neck Surgery, Chungnam National University College of Medicine 640 Daesa-Dong, Chung-Gu, Daejeon, 301-721, Korea Tel: +82-42-280-8228, Fax: +82-42-253-4059

E-mail: strive1005@cnu.ac.kr/strive1005@gmail.com
술 자체가 바이러스 전파의 고위험군이며, 치료 후 흡인 이나 폐렴에 취약한 상태이기 때문에 COVID-19에 감염 될 경우 특히 더 위중한 경과를 보일 수 있으며, 기관절개 술이나 기관-식도루 등의 특수한 상황이 있어 보다 세심 한 주의를 요한다. 현재까지 전세계적으로 구체적이고 명확한 지침은 마련되어 있지 않지만, 본 고에서는 기존 에 보고된 데이터들과 최근 대한암학회와 국립암센터에 서 의료진을 위해 마련한 COVID-19 상황에 기반한 암 환자 진료에 대한 권고사항을 기반으로 COVID-19 유행 의 상황에서 두경부암 환자의 진단 및 치료 시에 고려할 사항들에 대해서 정리해보고자 한다. 


\section{본론}

\section{SARS-CoV-2 infection (COVID-19)의 세계적인 대유 행 (Pandemic)과 우리나라 현황}

2020년 3월 12일 세계보건기구(World Health Organization, WHO)는 1968년 홍콩 독감, 2009년 신종플루 이후 세 번 째, 대유행(pandemic)을 선언하고, 신종 코로나바이러스감 염증-19 (SARS-CoV-2 infection, Coronal virus disease 2019, 이하 COVID-19)과 관련하여 전 세계가 모두 합심하여 범 국가적 총력을 다하여 노력할 것을 강조하였다. COVID-19 는 2019년 12월 중국 후베이성 우한시에서 발생하여 2020 년 1월 20 일 우리나라에서 첫 환자가 발생한 이후 특정 종교집단을 중심으로 폭발적인 증가와 전파/확산이 전 국적으로 진행하였으며, 2020년 4월 26일 현재 전국적으로 약 60 만명에 대해서 진단검사를 시행하였으며, 그 중 누적 확진자가 10,728 명, 사망자는 242 명, 완치 격리해제자는 8,717 명에 달하고 있다. WHO 통계자료 상, 전 세계 확진자 약 278만명, 사망자 약 19만명(https://covid19.who.int)에 달 하고 있으며, 전체적으로 $20 \sim 30 \%$ 정도가 중증 감염을 보 였으며, 치명률은 1.4 7.2\%로 보고되었다. ${ }^{1)}$ 특히 70세 이 상의 고령이거나 기저질환이 있는 환자에서는 사망률이 $8.0 \sim 22.5 \%$ 까지 보고된 바 있다. ${ }^{2)}$

환자 대부분이 경증이지만, 증상이 경미한 발생 초기 부터 전파가 일어나는 특징이 있어 지역사회로 급격히 확산되었고 고령이나 기존에 다양한 기저질환으로 인해 면역이 저하된 환자들은 감염의 확률이나 중등도가 높 아, 첫 환자 발생 후 한 달여 만에 우리나라 감염병 위기 경보 수준은 '경계'에서 '심각'으로 최고 수준까지 상향 되었고, 국민 개개인의 건강 문제를 넘어서, 지역별 의료 진, 의료시설 등의 의료자원 공급과 배분 문제, 마스크 사재기, 방역을 위한 ‘사회적 거리두기'로 인한 사회 경 제적 활동 위축에 따른 위기, 감염병 불안에 따른 휴원, 휴교 조치 등 다양한 문제들이 복합적으로 발생하여 사 회 전반에 지대한 영향을 주고 있다.

\section{COVID-19와 두경부암}

암 환자들은 암 자체 뿐만 아니라, 수술이나 항암방사선 치료로 인해 전신적인 면역력이 정상인에 비하여 약화된 상태이므로, 비단 SARS-CoV-2 뿐만 아니라, 다양한 종류 의 감염에 취약하다고 할 수 있다. ${ }^{2}$ 그러므로 두경부암 환자들이 바이러스에 노출되었을 때 감염에 이환될 확률 이 더 크다는 것은 쉽게 유추할 수 있다. 제한적인 초기 보고였지만, 중국의 575 개 병원의 1590 SARS-CoV-2 감염 증례에 대하여 분석한 연구의 결과를 보면, 18 명의 환자
(약 $1 \%$ )가 암 환자였으며, 이는 전체인구대비 높은 비율 $(0.29 \%, 2015$ 년 통계 기준)이었다. 그중 $28 \%$ 가 폐암 환자 였고, $25 \%$ 는 한 달 이내에 수술 혹은 항암방사선치료를 받은 환자들이었으며, 이 환자들은 정상인에 비해서 약 3.6배 더 COVID-19의 심각한 합병증(ICU 입실, 인공호 흡기 사용, 사망)을 동반하였다(hazard ratio $3.56,95 \%$ CI 1.65-7.69). ${ }^{3)}$ 위 연구를 진행한 저자들은 1) 소유행(endemic) 지역에서는 보조항암화학요법(adjuvant chemotherapy)이 나 비교적 진행이 빠르지 않은 암에 대한 정규 수술은 연기하는 것을 권고하였고, 2) 현재 투병하고 있는 환자 혹은 암 생존자를 위한 더 강력한 개인 보호 규정이 만들 어져야 한다고 하였다. 또한 3) 암 환자가 SARS-CoV-2에 감염되었을 때, 특히 고령이거나 기저질환이 있는 환자 들에게는 일반적인 경우보다 더 집중적인 감시나 치료를 고려해야 한다고 주장하였다. 이후 Zhang 등이 암 환자 에 대한 COVID-19의 위험성을 분석한 결과, 1276 명의 COVID-19 환자 중 28명(2.2\%)이 고형암환자(식도, 간, 위, 비인강암)였고, 사망률은 전체 COVID-19 환자 사망률의 약 10 배에 해당하는 $28.6 \%$ 로 보고하였다. 또한 이 연구 에서 최근 2 주 이내의 항암화학요법, 방사선치료, 면역치 료 등의 항암치료의 시행 여부가 사망을 포함한 중증 COVID-19감염을 예측하는 데 매우 중요한 인자인 것으 로 보고하였다. 물론 위의 연구들은 모두 중국에 국한하 여 분석한 것이고, 중증 감염을 중환자실 입실, 사망과 같이 극한적인 상황으로만 정의하였다는 점, 상대적으로 면역이 보다 억제되어 감염성 질환의 경과가 보다 심각 할 수 있는 혈액암을 배제하고 고형암에 대해서만 분석 하였다는 점 등에서 해석에 주의를 해야 하지만, 분명한 것은 암 환자들은 COVID-19에 더 취약할 것으로 예상되 며, 대유행 상황에서 환자의 치료와 경과 관찰에 있어서 COVID-19 상황을 고려해야 한다는 것이다. 적어도 암 환 자들의 사회적 거리두기나 자가격리의 기준은 일반인보 다 더 엄격하게 적용해야 하며, COVID-19 감염이 의심되 는 경우에는 바이러스 진단 검사, 흥부 방사선 촬영 등 신속한 평가가 이루어져야 한다. 실제로 최근 국내에서도 폐렴 증세로 응급실을 찾은 74세 남성 암 환자가 COVID-19 확진 판정을 받았는데, 이 환자는 1주 전 입원했던 것으 로 확인되었고, 밀접 접촉자에 대한 검사 결과 다른 암 환자, 또 다른 입원환자와 보호자, 의료진 7명도 감염된 것으로 확인되어 암 환자 감염의 심각성에 대해서 상기 한 바 있어 현재 식품의약품안전처와 질병관리본부도 '코로나19 예방을 위한 마스크 사용 권고사항'에서 면역 억제제 복용 환자, 항암치료 암 환자 등 건강취약계층의 경우 보건용 마스크를 반드시 착용하도록 권고했다. ${ }^{4)}$ 


\section{COVID-19 대유행 상황에서의 안전한 두경부암 치 료의 어려움}

SARS-CoV-2 바이러스는 잠복기는 5 일이고 14 일 이내 에 $99 \%$ 환자에서 증상을 유발하는 것으로 알려졌다. ${ }^{5)}$ 그러나 잠복기 기간에도 전염력이 있으며, 7 13\%에서는 증상이 전혀 없거나 미미하여 의심하기가 어려워 방역에 어려움을 겪고 있는 실정이다. 또한 점점 개선되고 있긴 하지만, 바이러스 진단 검사 자체도 위음성이 3 68\%까 지 높게 보고되어, 1 차 검사에서 음성이 나왔으나, 2 차 혹은 수차례 검사를 시행한 다음에야 양성으로 보고된 경우도 있다.

또한 SARS-CoV-2 바이러스는 비강, 비인두, 인두 등 두경부암의 주요 원발부위에서 증식하는 것으로 알려져 있고, 무증상인 환자들도 실제로 두경부 부위에서 높은 바이러스 역가를 확인할 수 있다. 이러한 바이러스는 최 소 3 시간 이상 에어로졸 형태로 공기 중에 남아서 전염을 유발할 수 있다. ${ }^{6}$ 수술을 위해 필요한 기도삽관 및 전신 마취는 대표적으로 에어로졸을 유발하는 술기이며, 두 경부암 수술은 레빈튜브(Levin-tube) 삽입, 기관절개술, 다 양한 공간의 음압흡인, 전기소작기, 에너지 장비(ultrasonic or advanced bipolar based)의 사용 등 대부분의 술기에서 지속적으로 에어로졸이 발생하게 된다. 물론 혈액에도 바이러스가 순환할 수 있지만, upper aerodigestive tract (UADT)에 대한 수술이 아닌 경부절제술(neck dissection), 이하선 절제술(parotidectomy), 갑상선 절제술(thyroidectomy) 과 같은 경우는 특별히 바이러스 전파의 고위험군이라고 하기는 어렵다.

또한 실제 수술을 시행할 때, 적절한 개인보호장비(personal protective equipment, PPE)를 갖추는 것은 현실적으로 쉽 지 않다. 두경부암 수술의 난이도와 복잡성, 때때로 유리 피판을 이용한 재건수술의 필요성 등을 고려하였을 때, 이러한 어려움은 결국 종양학적인 예후에도 연결되어 환자에게 또다른 위험을 안겨준다고 할 수 있다. 그러므 로, COVID-19 대유행의 상황에서는 두경부암 수술에 대 하여 매우 신중하게 선택하여 진행할 필요가 있다.

무증상의 초기 두경부암에서 정규수술을 지연하는 문 제에 대해서는, 타암종, 예컨대 정기검진에서 우연히 발 견된 무증상의 초기유방암(stage I or II)에 대해서는 감염 의 유행이 조절될 때까지 최대 60 일정도 연기하는 것은 가능한 것으로 보고되어 있지만, ${ }^{7)}$ 두경부암에 대해서는 보고된 바가 없어 결정의 근거가 제한적이다. 또한 감염 병의 유행이 언제까지 지속될 지 알 수 없다는 불확실성 으로 인해 언제까지 연기할 것인지 결정하는 것은 매우 어렵다. ${ }^{8)}$ 두경부암에 대한 다양한 연구에서 원발부위의
크기와 위치에 관계없이 대략 1 3개월 사이에 원발종양 혹은 가장 큰 림프절 전이의 크기가 약 2 배가 되는 것으 로 알려져 있다. 그러므로 일반적인 상황에서 저자를 포 함한 두경부암 수술 집도의는 환자가 진단 후, 아무리 늦어도 한 달 이내에는 치료가 시작될 수 있도록 부단한 노력을 한다. 그러나 최근에는 COVID-19 전파를 막기위 해 정책적으로 시행하는 '사회적 거리두기'로 인하여 환 자의 진료예약일정 취소, 수술연기, 입원지연 및 다학제 팀의 회의 일정 취소 혹은 지연, 진료 및 수술을 위한 $\mathrm{PPE}$ 의 보급지연 등 다양한 요인에 의하여 두경부암 환자 의 치료일정은 영향을 받을 수밖에 없을 것이며, 그로 인하여 평소보다 두경부암 환자들의 병기가 진행이 될 것이다. 또한 다양한 연구를 통해 알려진 것처럼, ${ }^{9-12)}$ 이 러한 지연은 필연적으로 두경부암 치료성적을 악화시키 게 된다. 그러나 4 6주 이내에 치료를 시작할 수 있으며, 환자의 증상과 조직학적 아형이 공격적이지 않은 경우, 어느 정도의 지연은 COVID-19 대유행의 현재 상황에서 는 감수해볼 수 있을 것이다. ${ }^{9}$ 그러나 이러한 지연이 전 체적인 치료성적뿐만 아니라, 더 큰 절제나 더 넓은 범위 의 방사선치료로 인하여 치료 후 환자의 기능이나 삶의 질에 영향을 줄 수 있다는 것은 반드시 고려해서 상황과 환자의 상태, 의료진 및 기관별 상황에 맞추어 다학제적 인 판단이 필요하다.

대유행상황에서도 항암화학요법이 암 환자 치료에서 가지는 이득은 변하지는 않는다. 다만, Liang 등이 보고 한 것처럼, ${ }^{13)}$ 이득과 위험의 균형에서 변화가 오기 때문 에, 이를 환자에게 충분히 알리고 환자의 상태 뿐만 아니 라, 지역별 유행의 정도와 가용한 의료자원 등을 다양하 게 고려하여 신중하게 선택해야 한다.,14) 또한 항암치료 자체에 대해서도 보다 덜 효과적일 수는 있으나, 면역억 제가 비교적 적은 용법을 선택하는 것에 대해서 환자에 게 충분한 정보를 제공하고 선택에 참여할 수 있도록 해야한다. ${ }^{14)}$ 보조치료(adjuvant therapy)의 경우, 현재 감 염병의 대유행 상태에서 언제까지 연기할 수 있는지에 대해서 보고된 바는 없으나, 많은 보고에서 일반적으로 두 경부암에서 6 주 이내에 시작할 것을 권고하고 있으며, ${ }^{15,16)}$ Treatment package time (TPT)이 100일을 넘지 않는 것이 생존율 향상에 유의한 인자로 보고되어 있어, ${ }^{17)}$ 수술 후 최대 6주까지는 언급한 다양한 상황을 고려하여 일정을 연기할 수 있겠으나 향후 대규모 연구를 통해 대유행이라 는 특수한 상황에서의 가이드라인이 제시되어야 하겠다. 방사선치료는 분할치료가 매일매일 이루어지며, 중간 에 일정을 멈추는 것이 허용되지 않는다는 점에서 매우 특수한 상황이다. 그러므로, 감염이 확인되지 않았다면, 
기존에 진행 중이던 치료는 지속하는 것이 좋겠다. ${ }^{18)}$ 외 래진료, 항암제 주사, 수술 등은 COVID-19가 의심되거 나 노출된 기왕력이 확인된 환자의 경우는 격리된 공간 에서 진행하는 것이 가능할 수 있지만, 방사선 치료는 시뮬레이터, 선형가속기 등 장비가 다양하고 넓은 공간 이 필요하여 격리된 공간을 구성하는 것이 현실적으로 어렵다. 미국방사선종양학회(American Society of Radiation Oncology, ASTRO)에서 최근에 발표한 지침은 모든 방사 선치료 환자는 예약 전 COVID-19에 대한 스크리닝 검사 를 시행하고, 가능하다면 N95 마스크를 착용하도록 하였 다. 새롭게 시작하는 암 환자의 경우 두경부에 대해서는 언급하고 있지 않으나, 전립선, 유방암 및 뇌수막종, 신경 초종과 같은 중추신경계 양성종양의 경우 최소 2 개월 이상 일정을 뒤로 미룰 것을 권고하였다. 고식적인 치료 의 경우에도 적절한 평가를 통해 생명을 위협하는 증상 (spinal cord compression, cauda equina compression, cranial nerve compression, superior vena cava syndrome, airway obstruction, hemoptysis or other bleeding from the tumor)이 아닌 경우에는 일정을 연기하도록 권고하였다. ${ }^{19)}$

\section{진단}

COVID-19 대유형의 상황에서도 암 환자를 시기적절 하게 진단하고 치료하는 것은 반드시 필요하지만(Fig. 1), 두경부라는 원발 부위의 특성상 COVID-19 감염이 의심 되는 암 환자에서는 진단이나 치료를 위한 시술이 바이 러스 전파의 위험을 증가시키는 것이 환자의 치료나 예 후에 어떤 영향을 주는지 잘 저울질하여 신중하게 진행 해야 하며, 확진 환자에게 꼭 필요한 내시경적 시술은 에어로졸 유발하는 시술 시 갖추어야 하는 보호장비를 갖추고, 음압시설이 갖추어진 독립된 공간에서 해야 할 것이다. ${ }^{1)}$

2020년 4월 29일 대한암학회와 국립암센터에서 우리 나라의 COVID-19 상황에 기반한 암 환자 진료에 대해 의료인을 대상으로 하는 권고사항을 공동 발표한 '코로

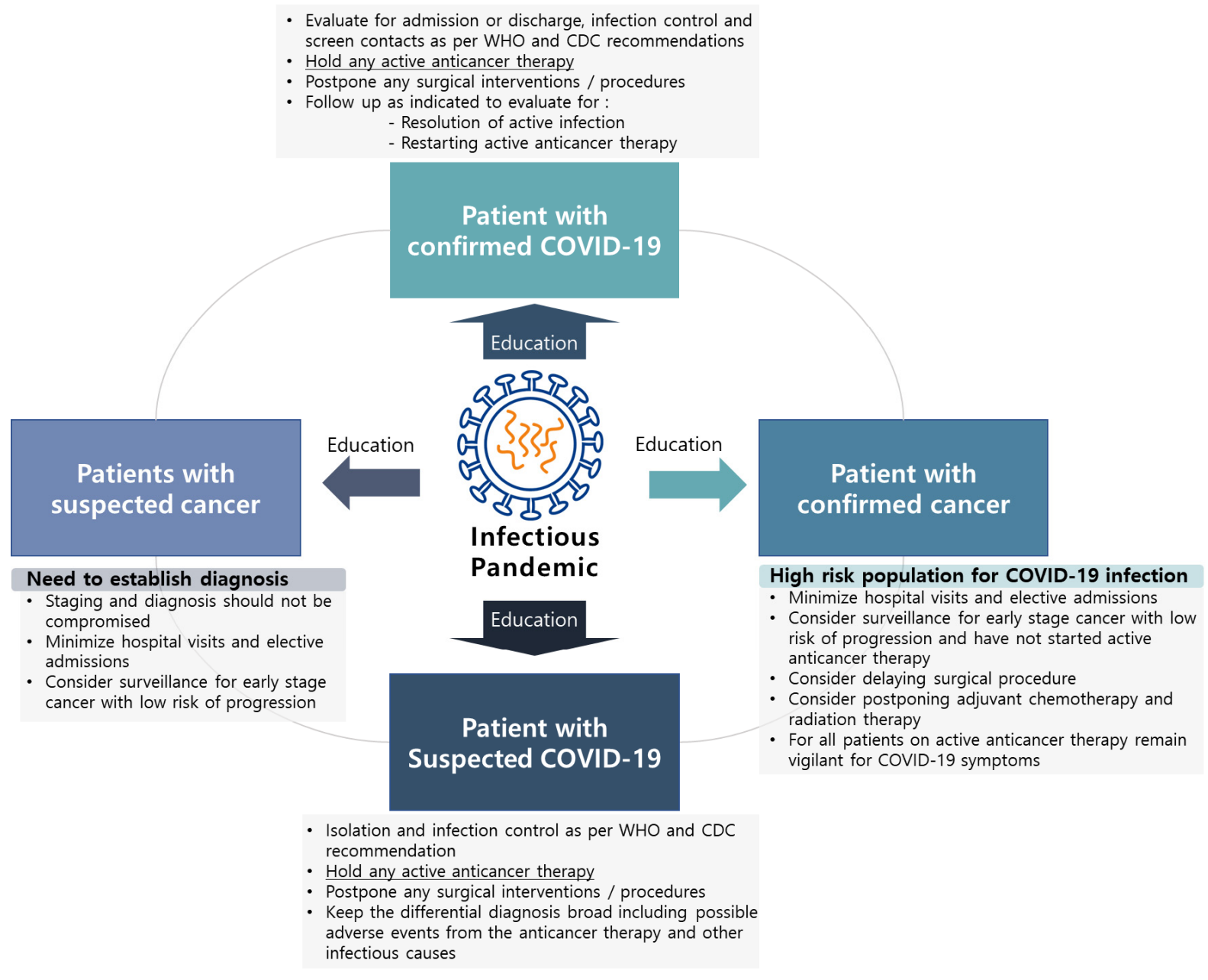

Fig. 1. Suggested consideration for head and neck oncologic care in the context of COVID-19 infectious pandemic (modified from A Practical Approach to the Management of Cancer Patients During the Novel Coronavirus Disease 2019 (COVID-19) Pandemic: An International Collaborative Group. Oncologist. 2020.) 
나19 암 환자 권고사항’은 건강한 일반인을 대상으로 하 는 암 검진의 경우, 예정된 암 검진은 시행하고 COVID-19 감염의 확산으로 의료 자원이 부족해지는 상황에서는 안정화될 때까지 검진을 연기할 것을 권고하였다. 이를 근거로 검사 전 발열, 호흡기 증상 등의 선별 문진을 시행 하여 무증상일 경우 암 검진을 시행하며, COVID-19 선 별검사 양성일 경우, 음성으로 전환될 때까지 내시경 검 사를 연기하는 것이 좋겠다.

\section{치료 및 경과 관찰}

COVID-19의 세계적인 대유행 상황에서, COVID-19의 전파를 줄이기 위해 덜 공격적인 암의 치료를 지연시키 는 것이 종양 진행의 위험보다 어떠한 경우에는 더 중요 할 수도 있지만, ${ }^{1,30)}$ 어느 한 가지 요인으로 치료 시작/중 단 여부를 결정하기는 쉽지 않다. 북미와 유럽의 다양한 지침이 산발적으로 공유되고 있으나, 근거를 가지고 구 체화된 지침은 아직까지 없는 실정이다. 두경부암 환자 치료의 복잡 다양한 상황으로, 구체적인 가이드라인이 절실히 필요한 상황이지만, 아직까지는 풀어나가야 할 많은 과제들이 있다. 어떤 수술을 얼마나 미뤄야 하는가? 항암화학요법이나 방사선 치료와 같은 암 치료는 일정을 미뤄야 하는가? 미뤄야 한다면, 어떤 환자들을 얼마나 미뤄야 하는가? 암 환자들은 일반 인구와 비교하여 COVID-19 감염에 대한 차등 선별 과정을 거쳐야 하는 가? 암 환자 입원 시 병원 감염은 어떻게 효과적으로 줄 일 수 있을 것인가? 향후 COVID-19 백신이 개발된다면, 독감백신처럼 암 환자들에게 예방적으로 접종을 해야 할 것인가? 아직 위 물음들에 대한 명확한 대답은 하기 어렵겠지만, 암 환자에게 통합적인 치료(Comprehensive management)를 제공하고, 환자와 함께하는 의료진들에 게 COVID-19는 향후 지속적으로 고려되어야 하는 새로 운 요소인 것은 분명해 보인다. 최근 발표된 우리나라의 가이드를 포함하여, 일반적으로 받아들여지는 가이드에 따르면, COVID-19로 확진된 경우 진행 중인 암 치료는 중단하고 COVID-19 치료를 선행하는 것에 대해 의료진 과 상의해야 한다(Fig. 1). 그러나 진행된 암이나 공격적 인 아형의 암에서 COVID-19 전파를 줄이기 위해 치료를 지연시키는 것은 논란이 있으며, 환자별, 기관별, 지역별 상황과 인프라에 따라서 결정해야 할 것이다.

최근 대한암학회와 국립암센터에서 공동 발표한 '코 로나 19 암 환자 권고사항, 중 치료와 관련된 부분을 요약 하면 아래와 같다. ${ }^{4}$

\section{1) 일반적 권고사항}

암 환자가 COVID-19로 확진이 되었을 경우 진행 중인 암 치료(예정된 비응급 수술, 항암치료, 방사선치료)는 중단하고, 취약한 고위험군이므로 입원하여 COVID-19 치료를 선행하도록 하였고, 완치되면 암 치료를 시작하 도록 한다.

\section{2) 암 환자의 수술에 대한 권고사항}

암 환자의 수술을 지연시킬 경우 병이 진행될 가능성이 있으므로 수술을 연기하지 않는 것을 원칙으로 하나, 수 술 시행/연기 여부는 환자 상태, 기관별 상황(COVID-19 감염 환자 입원 여부, 의료진, 중환자실, 병상 등의 의료 자원)을 고려하여 담당 의사의 판단에 따라 환자와 면담 후 환자별로 결정한다. 정규 수술에 대한 COVID-19 선 별검사는 병원 정책에 따라 진행하고, 응급 수술은 즉각 수술을 시행하되 발열이 있는 경우 COVID-19 선별검사 를 시행한 후 진행한다.

수술 시 세부 보호구 목록은 다음과 같다.

-2겹의 수술 장갑, N95 마스크, 보안경 또는 안면 보호

구(facial shield), 머리 커버, 방수성 수술복, 신발 커버 - COVID-19로 진단되었거나 양성이 예측되는 경우에 는 Enhanced PPE (Level D + 전동식 공기정화호흡기 (PAPR))를 적용한다.

\section{3) 암 환자의 항암치료에 대한 권고사항}

COVID-19의 지역별 유행 정도와 항암치료의 목적에 따라서 결정하도록 권고하고 있다. 소유행(지역사회 산 발적 발생)의 경우 치료받는 환자의 COVID-19 감염 위 험이 낮은 경우 통상적인 항암치료를 지속할 수 있으나, 대유행(지역사회 대규모 전파 및 대량의 확진 환자 발생) 으로 치료받는 환자의 COVID-19 감염 위험이 높고 의료 자원 부족으로 암 환자의 정상 치료에 장애가 발생한 경우, 입원 회피, 외래 일정 조정, 약제 사용 조정(가능한 경우 경구 항암제로 변경, 최대한 투여 주기 연장하는 요법 선택)이 필요하며, 보조 항암제 치료를 앞둔 암 환 자의 경우 주치의와 상의하에 일정 조정 또는 치료 가능 한 타 지역에서 치료를 진행해 볼 수 있다. 진행성 또는 전이성 고형암으로 고식적 항암치료를 시행 중이거나 계획 중인 암 환자의 경우, 증상이 있거나, 병의 진행이 빠른 경우 항암치료를 늦춰서는 안되지만, 병원 방문 횟 수를 줄이기 위한 대책을 고민해야 한다. 증상이 없는 경우에는 고형암에 대한 항암치료 전에 COVID-19 선별 검사를 반드시 할 필요는 없다. 


\section{4) 암 환자의 방사선치료에 대한 권고사항}

신환 및 초진 환자의 방사선 치료의 경우, 국내 현시점 에서 방사선 치료 시작 연기를 고려하지 않으나, 감염 확산으로 의료자원이 부족할 시에 방사선 치료 시작 일정 연기를 검토한다.

방사선 치료 분할 요법은 감염 확산으로 지역사회 의 료자원이 부족한 경우 가능한 소분할 요법을 고려하며, 방사선 치료 중인 환자가 COVID-19 확진 시, 환자의 신 체 기능 및 생명을 위협하는 상황이 아니면 방사선 치료 를 중단하고 COVID-19 완치 판정 이후 이전 중단 기간을 고려하여 총 방사선량의 증량을 고려한다. 방사선 치료 후 COVID-19 양성 환자의 재진 진료는 완치 이후로 연 기하는 것을 권고한다. 방사선치료 종료 이후 부작용/합 병증이 없거나 예후가 양호할 것으로 판단되면 재진은 가능한 3 개월 이상의 간격을 두지만, 사례별로 일정을 조정한다.

\section{5) 소아청소년 암 환자의 진료에 대한 권고사항}

소아청소년 암 환자의 COVID-19 관련 위험은 더 클 가능성을 고려하여야 하며, 감염된 소아청소년 암 환자 진료 시 중증질환으로의 진행 가능성이 높다. 항암치료 는 반드시 시행해야 할 치료를 연기할 필요는 없으나, 항암치료나 수술을 받은 지 한 달 이내 감염이 발생했을 경우, 중증질환으로 진행 확률이 높으므로 이를 고려하 여 치료한다. 항암치료를 종결한 장기 추적 관찰 환자의 경우 외래 진료 연기 및 전화 진료 대체 등을 고려할 수 있다. 조혈 모세포 이식 관련해서는 COVID-19 유행에 따른 혈액제제 수급 차질로 적기에 수혈이 이루어지지 않을 가능성을 대비해 혈액 제제의 원활한 수급 대책을 미리 논의한다.

물론 최근 보고된 암 환자의 입원에 대한 코호트 연구 에서 보고한 바와 같이 암 환자의 입원은 많은 경우 피할 수 없는 경우가 많아서(74.1\%는 medical emergency, $79.6 \%$ 는 uncontrolled symptom including dyspnea, pain, neurological symptoms), ${ }^{21)}$ 위의 권고사항에서 제시하는 입원 회피는 현실적으로 쉽지 않은 경우가 많을 것으로 생각 된다. 또한 위암, 대장암, 간암, 자궁경부암, 폐암, 유방암 에 대하여 세부권고사항을 제시하고 있으나, 두경부암 에 대해서는 세부사항을 정하지는 않았다. 그러나, 두경 부암의 바이러스 접촉 위험이 다른 암종에 비하여 상대 적으로 크다는 점을 고려하고, 기관튜브나 영구기관절 개공, 기관-식도루 등 특수한 상황이 있다는 점을 고려하 면, 두경부암 관련 전문가들이 향후 신종감염병의 유행
에 대비하는 세부진료지침 팀에 반드시 포함되어야 하며, 세부 권고사항이 제정되어야 할 것이다.

\section{두경부암의 특수상황}

많은 두경부암 환자들은 수술 후 기관절개창과 튜브를 가지고 있는 경우가 많으며, 후두 전 절제술을 받은 경우 일반적인 호흡과는 다른 호흡 생리 구조를 가지게 되어 다른 암 환자보다 호흡기 관리에 특별한 주의를 요한다.

\section{1) 폐쇄호흡희로환기(closed circuit ventilation)}

COVID-19 상황에서 폐쇄호흡회로환기가 바이러스 전 파를 막는데 효과적으로 이용될 수 있다. 이 경우 커프(cuff) 가 있는 기관튜브를 사용해야 한다. 흡인이 필요할 때는 폐쇄형 흡인기(in-line suction device)를 사용해야 하며, nebulizer는 가능한 최소화한다.

\section{2) 열습도교환기(heat moisture exchange unit, HME)}

$\mathrm{HME}$ 는 에어로졸의 발생을 효과적으로 줄여주는 것으 로 알려져 있으며, 최근 후두절제술을 받은 환자들을 위 해 개발된 Provox ${ }^{\circledR}$ Micron $\mathrm{HME}^{\mathrm{TM}}$ 과 같은 $\mathrm{HME}$ 는 바이 러스를 약 $99 \%$ 정도 걸러준다고 한다. ${ }^{22)}$ 이는 연결단자를 사용할 경우 기관튜브에도 사용이 가능하다. HME를 사 용할 때도 인두와 비강으로의 공기흐름이 유출되는 것을 방지하기 위해 커프가 있는 기관튜브를 사용하는 것이 좋겠다. ${ }^{22}$

\section{3) 개인보호장비(PPE)}

COVID-19가 확진된 두경부암 환자를 진찰하는 의료 진은 최소한 N95 마스크, 안면 보호구, 가운, 글러브를 항상 착용해야 한다. 무증상이나 음성인 환자의 경우 일 반 수술용 마스크를 사용할 수 있지만, 이 경우에도 안면 보호구, 가운, 글러브를 병실에서 항상 착용해야 한다. 그러나 음압을 이용한 석션이나 튜브 교환 등 어떠한 종 류라도 시술이 필요하다면, COVID-19 양성/음성 여부와 관계없이 항상 N95 마스크를 착용하는 것이 좋겠다. ${ }^{22,23)}$ 환자의 경우에도 COVID-19 양성이거나 검사가 진행 중인 환자는 기관절개창의 유무와 관계없이 수술마스크 를 반드시 착용해야 하며, 음성인 환자라도 면역이 떨어 져 있거나, 항암 방사선 치료를 받은 환자, 최근 1년 이내 에 이식수술을 받은 환자들도 마스크를 착용하는 것이 필요하다. ${ }^{22)}$

\section{4) 개인위생}

바이러스 전파 방지에 손 위생은 중요하고 확실한 방 
법 중의 하나이며, 기관 절개창을 가진 환자들은 튜브나 절개창을 만질 때마다 손 위생을 철저히 해야 한다. 인공 후두장치를 사용하는 환자는 장치를 청결하게 유지하기 위해 수시로 닦아주는 것이 필요하다. ${ }^{22)}$

\section{5) 술기의 최소화}

감염이 우려되는 환자에게 정기적인 튜브 교환이나 Provox와 같은 발성을 위한 장치의 교환은 연기하는 것 이 필요하며, 기관-식도루의 헐거워짐이나 새는 것은 일 시적인 마개를 사용하거나 점도가 있는 연고 등으로 일 시적으로 처치해 볼 수 있다. 또한 불필요한 외래 방문 일정 또한 줄이거나 한시적으로 허용된 유선 연락을 통 해 진행하는 것을 고려해볼 수 있다. ${ }^{24)}$

\section{6) SARS-CoV-2 스크리닝}

환자 개개인별, 병원별, 지역별 특성을 고려하여 결정 해야 할 것이나, 위험률을 고려하였을 때, 기관절개술이 나 후두 전 절제술이 예정된 모든 환자에서 바이러스 스 크리닝이 필요하다. 또한 기관 절개창이 있는 환자가 입 원을 할 경우에도 입원 전 스크리닝을 고려하는 것이 좋 겠다. ${ }^{22,25)}$

\section{결론}

암 환자는 일반인에 비하여 COVID-19에 대한 고위험 군으로 적극적인 감시와 대비가 필요하다. 진단과 치료 가 COVID-19 유행으로 인해 늦어질 수 있고 이는 생존 율과 연결될 수 있어 득과 실을 고려하여 합리적인 선택 이 필요하지만 특히 두경부에서는 제한된 근거로 인해 지침이 부족한 실정이다. 현재 COVID-19가 확진될 경우 진행 중인 항암치료를 중단하고 COVID-19 치료를 선행 하는 것으로 하고 있으나, COVID-19 치료 및 전파 방지 와 동시에 진단과 치료가 늦어지지 않도록 하는 것이 중요할 것이다.

두경부암의 치료는 원발 부위의 특성상 먹고, 마시고, 숨 쉬는 기능적 측면에, 사회적, 심리적, 미용적 측면이 다양하고 복합적으로 관련되어 복잡하고 다양한 고려사 항이 있어, 다학제적 접근이 필요하다. 이에 더하여, 전례 없이 COVID-19라는 새로운 변수가 큰 영향을 주고 중요 한 고려 사항이 되고 있으나, 새로운 도전과 함께 두경부 암 치료와 관련된 다양한 분야의 전문가들이 함께 힘을 합친다면 반드시 합리적인 근거 중심의 새로운 해결책이 나올 것으로 기대하며, 향후 유사한 신종감염병의 유행 에 대비할 수 있을 것으로 생각한다.

\section{Acknowlegment}

This work was supported by the Basic Science Research Program through the National Research Foundation of Korea funded by the Ministry of Science, ICT and Future Planning (2016R1D1A1B0493211) and the research fund of Chungnam National University Hospital (2018-CF-031).

\section{References}

1) Day AT, Sher DJ, Lee RC, Truelson JM, Myers LL, Sumer BD, et al. Head and neck oncology during the COVID-19 pandemic: Reconsidering traditional treatment paradigms in light of new surgical and other multilevel risks. Oral Oncology. 2020:104684.

2) Day AT, Sher DJ, Lee RC, Truelson JM, Myers LL, Sumer BD, et al. Head and neck oncology during the COVID-19 pandemic: Reconsidering traditional treatment paradigms in light of new surgical and other multilevel risks. Oral Oncol. 2020;105:104684.

3) Liang W, Guan W, Chen R, Wang W, Li J, Xu K, et al. Cancer patients in SARS-CoV-2 infection: a nationwide analysis in China. The Lancet Oncology. 2020;21:335-337.

4) KCA. Recommendations for cancer patient care based on the situation of COVID-19 in Korea; 2020.

5) van Doremalen N, Bushmaker T, Morris DH, Holbrook MG, Gamble A, Williamson BN, et al. Aerosol and Surface Stability of SARS-CoV-2 as Compared with SARS-CoV-1. New England Journal of Medicine. 2020;382:1564-1567.

6) Santarpia JL, Rivera DN, Herrera V, Morwitzer MJ, Creager H, Santarpia GW, et al. Transmission potential of SARS-CoV-2 in viral shedding observed at the University of Nebraska Medical Center. medRxiv. 2020.

7) Mansfield SA, Abdel-Rasoul M, Terando AM, Agnese DM. Timing of Breast Cancer Surgery-How Much Does It Matter? Breast J. 2017;23:444-451.

8) Al-Shamsi HO, Alhazzani W, Alhuraiji A, Coomes EA, Chemaly RF, Almuhanna M, et al. A Practical Approach to the Management of Cancer Patients During the Novel Coronavirus Disease 2019 (COVID-19) Pandemic: An International Collaborative Group. Oncologist. 2020.

9) DeGraaff LH, Platek AJ, Iovoli AJ, Wooten KE, Arshad H, Gupta $\mathrm{V}$, et al. The effect of time between diagnosis and initiation of treatment on outcomes in patients with head and neck squamous cell carcinoma. Oral Oncology. 2019;96:148-152.

10) Graboyes EM, Kompelli AR, Neskey DM, Brennan E, Nguyen $S$, Sterba KR, et al. Association of Treatment Delays With Survival for Patients With Head and Neck Cancer: A Systematic Review. JAMA Otolaryngol Head Neck Surg. 2019;145:166-177.

11) Ho AS, Kim S, Tighiouart M, Mita A, Scher KS, Epstein JB, et al. Quantitative survival impact of composite treatment delays in head and neck cancer. Cancer. 2018;124:3154-3162.

12) Jensen AR, Nellemann HM, Overgaard J. Tumor progression in 
waiting time for radiotherapy in head and neck cancer. Radiother Oncol. 2007;84:5-10.

13) Liang W, Guan W, Chen R, Wang W, Li J, Xu K, et al. Cancer patients in SARS-CoV-2 infection: a nationwide analysis in China. Lancet Oncol. 2020;21:335-337.

14) Battershill PM. Influenza pandemic planning for cancer patients. Curr Oncol. 2006;13:119-120.

15) Harris JP, Chen MM, Orosco RK, Sirjani D, Divi V, Hara W. Association of Survival With Shorter Time to Radiation Therapy After Surgery for US Patients With Head and Neck Cancer. JAMA Otolaryngol Head Neck Surg. 2018;144:349-359.

16) Xiao R, Joshi RR, Husain Q, Cracchiolo JR, Lee N, Tsai J, et al. Timing of surgery and adjuvant radiation therapy for sinonasal malignancies: Effect of surgical approach. Head Neck. 2019;41: 3551-3563.

17) Ghanem AI, Schymick M, Bachiri S, Mannari A, Sheqwara J, Burmeister $\mathrm{C}$, et al. The effect of treatment package time in head and neck cancer patients treated with adjuvant radiotherapy and concurrent systemic therapy. World J Otorhinolaryngol Head Neck Surg. 2019;5:160-167.

18) Mukherjee RK, Back MF, Lu JJ, Shakespeare TP, Wynne CJ. Hiding in the bunker: Challenges for a radiation oncology department operating in the Severe Acute Respiratory Syndrome outbreak. Australas Radiol. 2003;47:143-145.

19) ASTRO. COVID-19 recommendations to radiation oncology $\mathrm{pr}$ actices. 2020; Available from: https://www.astro.org/Daily-Practi
ce/COVID-19-Recommendations-and-Information/Summary.

20) Ueda M, Martins R, Hendrie PC, McDonnell T, Crews JR, Wong $\mathrm{TL}$, et al. Managing Cancer Care During the COVID-19 Pandemic: Agility and Collaboration Toward a Common Goal. J Natl Compr Canc Netw. 2020:1-4.

21) Numico G, Cristofano A, Mozzicafreddo A, Cursio OE, Franco P, Courthod G, et al. Hospital admission of cancer patients: avoidable practice or necessary care? PLoS One. 2015; 10:e0120827.

22) Kligerman MP, Vukkadala N, Tsang RKY, Sunwoo JB, Holsinger FC, Chan JYK, et al. Managing head and neck cancer patients with tracheostomy or laryngectomy during the COVID-19 pandemic. Head Neck. 2020.

23) Michetti CP, Burlew CC, Bulger EM, Davis KA, Spain DA. Performing tracheostomy during the Covid-19 pandemic: guidance and recommendations from the Critical Care and Acute Care Surgery Committees of the American Association for the Surgery of Trauma. Trauma Surgery \&amp;amp; Acute Care Open. 2020;5:e000482.

24) Sommer DD, Engels PT, Usaf C, Khalili S, Corsten M, Tewfik $\mathrm{MA}$, et al. Recommendations from the CSO-HNS taskforce on performance of tracheotomy during the COVID-19 pandemic. $J$ Otolaryngol Head Neck Surg. 2020;49:23.

25) Adjei Boakye E, Jenkins W, Sharma A. Disproportionate impact of COVID-19 pandemic on head and neck cancer survivors. Head Neck. 2020. 